\title{
Pregnancy and COVID-19: What we Need to Know
}

\author{
Rachid Ait Addi ${ }^{1 \star}$, Abdelhafid Benksim ${ }^{1,2}$, Mohamed Cherkaoui ${ }^{1}$
}

\author{
${ }^{1}$ Laboratory of Human Ecology, Department of Biology, School of Sciences Semlalia, Cadi Ayyad University, Marrakesh, MOROCCO \\ ${ }^{2}$ High Institute of Nursing and Technical Health, Marrakesh, MOROCCO \\ *Corresponding Author: dr.rachid.aitaddi@gmail.com
}

Citation: Ait Addi R, Benksim A, Cherkaoui M. Pregnancy and COVID-19: What we Need to Know. Electron J Gen Med. 2020;17(6):em228. https://doi.org/10.29333/ejgm/7891

\section{ARTICLE INFO}

Received: 31 Mar. 2020

Accepted: 04 Apr. 2020

\begin{abstract}
Since the outbreak of the COVID-19 disease in wuhan china, the infection become a pandemic and a major public health concern all over the world. Pregnant women and their fetuses are at high risk of infectious disease outbreaks. Physiological and mechanical changes in pregnancy increase susceptibility to infections in general, particularly when the cardiorespiratory system is affected, and encourage rapid progression to respiratory failure during pregnancy. We need to further strengthen preventive measures amongst pregnant women against COVID19 , and to reinforce visit time and procedures in obstetric clinics and units with specialized infection control to limit the spread of the disease over the population especially the neonates.
\end{abstract}

Keywords: pregnancy, COVID-19, fetuse

Fairly, since the outbreak of the COVID-19 disease in wuhan china, the infection become a pandemic and a major public health concern all over the world.

The incubation period range is 2-14 days and it was found that people whom were hospitalized for COVID-19 were aged between 49 and 56 years, and almost half of them had chronic diseases. Also, the hospitalized cases were often men. Children have been rarely reported, and frequent manifestations include fever, cough, myalgia, headache, and diarrhea were noted amongst COVID-19 cases (1-3).

Pregnant women and their fetuses are at high risk of infectious disease outbreaks. Physiological and mechanical changes in pregnancy increase susceptibility to infections in general, particularly when the cardiorespiratory system is affected, and encourage rapid progression to respiratory failure during pregnancy. In addition, the Th2 system protects only the fetus during pregnancy, and leaves the mother vulnerable to viral infections, which are more effectively contained by the Th1 system (4,5). Furthermore, COVID-19 disease could generate fetal complications as miscarriage, intrauterine growth restriction, pre-term birth. Fever, which is the prevailing symptom in COVID-19 may also cause childhood inattention disorders due to hyperthermic injury to fetal neurons $(1,5)$.

Additionally, the clinical symptoms reported in pregnant women with confirmed COVID-19 infection were same as those reported for non-pregnant adults with confirmed COVID-19 infection in the general population $(6,7)$.

Controversies exist regarding whether SARS-CoV-2 can be transmitted in utero from an infected mother to her infant before birth. Indeed, several studies confirm absence of viral isolates in the amniotic fluid, cord blood, breast milk and neonatal throat swabs in a subset of these patients, however other studies found that neonates were infected with SARSCoV-2 (6-10).

In studies reporting pregnancies with COVID-19, all women were infected in the third trimester, and all women had a cesarean delivery $(6,7,10)$. Nevertheless, the small number of cases analyzed and the short duration of the studies period may create bias, which suggests that more advanced studies have to be conducted about the effect of COVI-19 disease on pregnant women and fetuses, the vertical transmission of COVID-19 from mother to fetus, and medical and preventive treatment of COVID-19 disease adapted to pregnant women to prevent side effects on the baby (11).

We need to further strengthen preventive measures amongst pregnant women against COVID-19, and to reinforce visit time and procedures in obstetric clinics and units with specialized infection control to limit the spread of the disease over the population especially the neonates.

\section{ACKNOWLEDGEMENTS}

The authors want to acknowledge the Editorial office of the journal and all the anonymous reviewers.

\section{REFERENCES}

1. Rasmussen SA, Smulian JC, Lednicky JA, Wen TS, Jamieson DJ. Coronavirus Disease 2019 (COVID-19) and Pregnancy: What obstetricians need to know, American Journal of Obstetrics and Gynecology. 2020. https://doi.org/10.1016/ j.ajog.2020.02.017 PMid:32105680 PMCid:PMC7093856 
2. Gondauri D, Mikautadze E, Batiashvili M. Research on COVID-19 Virus Spreading Statistics based on the Examples of the Cases from Different Countries. Electron J Gen Med. 2020;17(4):em209. https://doi.org/10.29333/ejgm/7869

3. Ait Addi R, Benksim A, Amine M, Cherkaoui M. COVID-19 Outbreak and Perspective in Morocco. Electron J Gen Med. 2020;17(4):em204. https://doi.org/10.29333/ejgm/7857

4. Yu N, Li W, Kang Q, Xiong Z, Wang S, Lin X, Liu Y, Xiao J, Liu $H$, Deng D, Chen S, Zeng W, Feng L, Wu J. Clinical features and obstetric and neonatal outcomes of pregnant patients with COVID-19 in Wuhan, China: a retrospective, singlecentre, descriptive study. Lancet Infect Dis. 2020 Mar 24. pii: S1473-3099(20)30176-6. https://doi.org/10.1016/S14733099(20)30176-6

5. Liang H, Acharya G. Novel corona virus disease (COVID-19) in pregnancy: What clinical recommendations to follow? Acta Obstet Gynecol Scand. 2020 Apr;99(4):439-42. https://doi.org/10.1111/aogs.13836 PMid:32141062

6. Dashraath P, Jing Lin Jeslyn W, Mei Xian Karen L, Li Min L, et al. Coronavirus Disease 2019 (COVID-19) Pandemic and Pregnancy, American Journal of Obstetrics and Gynecology 2020. https://doi.org/10.1016/j.ajog.2020.03.021 PMid: 32217113
7. Chen, J. Guo, C. Wang, F. Luo, X. Yu, W. Zhang, et al. Clinical characteristics and intrauterine vertical transmission potential of COVID-19 infection in nine pregnant women: a retrospective review of medical records. Lancet. 2020. https://doi.org/10.1016/S0140-6736(20)30360-3

8. Dong L, Tian J, He S, et al. Possible Vertical Transmission of SARS-CoV-2 From an Infected Mother to Her Newborn. JAMA 2020. https://doi.org/10.1001/jama.2020.4621 PMid:32215581

9. Calda $P$, Břešták M, Fischerová D, Zikán M, Smetanová D, Machala L. Koronavirová infekce a těhotenství (COVID-19). Stanovisko České společnosti pro ultrazvuk v porodnictví a gynekologii ČLS JEP. Actual Gyn. 2020;12:17-9. Available at: https://www.actualgyn.com/en/2020/242

10. Chen H, Guo J, Wang C, et al. Clinical characteristics and intrauterine vertical transmission potential of COVID-19 infection in nine pregnant women: a retrospective review of medical records. Lancet. 2020. https://doi.org/10.1016/S0140-6736(20)30360-3

11. Qia J. What are the risks of COVID - 19 infection in pregnant women? Lancet. 2020. https://doi.org/10.1016/S0140 6736(20)30365 - 2 